\title{
Perbedaan Tingkat Kesegaran Jasmani Siswa SD Negeri 13 Muara Siberut Dengan Siswa SD Negeri 06 Rogdog Kecamatan Siberut Selatan
}

\author{
Meiriani Armen \\ Correspondence: Keguruan dan Ilmu Pendidikan, Universitas Bung Hatta, \\ Padang, Indonesia. \\ E-mail: ria.pjkr12@bunghatta.ac.id
}

\begin{abstract}
The research aims to explain differences in physical fitness level of student SD Negeri 13 Muara Siberut with siswa SD Negeri 06 Rogdog subdistrict South Siberut. This type of research is computational. The population in this study is a classroom V SD Negeri 13 Muara Siberut dengan SD Negeri 06 Rogdog subdistrict South Siberut. Techniques used in the sampling is random sampling technique, which is sampling conditional. Thus the number of samples in this study is much 25 people female student. Techniques of data retrieval is done by testing TKJI (Tingkat Kesegaran Jasmani Indonesia) or the level of physical fitness Indonesia. Data were analyzed using mean difference test or $t$-test. The data analysis technique used is the difference ( $t$-test). By using $t$-test, apparently there are $t_{\text {hitung }}(2,26)$ while $t_{\text {alpha }}(1,88)$ with level 0,05 mean $t_{\text {hitung }}(2,66)>$ $t_{\text {alpha }}(1,88)$ so that Ho rejected dan Ha be accepted, so in conclusion there are different level of physical fitness of student SD Negeri 13 Muara Siberut dengan SD Negeri 06 Rogdog subdistrict South Siberut.
\end{abstract}

\section{Keywords: Difference, physical fitness}

\section{Pendahuluan}

Dalam rangka mewujudkan warga Negara yang berkualitas berdasarkan visi dan misi pembangunan nasional, pemerintah telah mengeluarkan UndangUndang RI No. 20 Tahun 2003 tentang fungi dan tujuan sistem pendidikan nasional "Sistem pendidikan berfungsi mengembangkan kemampuan dan membentuk watak serta peradaban bangsa yang bermartabat dalam mencerdasarkan kehidupan bangsa, bertujuan untuk berkembangnya potensi peserta didik agar menjadi manusia yang beriman dan bertaqwa kepada tuhan yang maha esa, berakhlak mulia, sehat, berilmu, cakap, kreatif, mandiri dan menjadi warga Negara yang demokratis serta bertangggung jawab".

Pendidikan jasmani dan kesehatan merupakan salah satu bidang studi yang menjadi muatan dalam kurikulum Sekolah Dasar. Bidang studi ini memuat dua materi, yatu: materi pokok dan materi pilihan. Materi pokok dalam Garis-garis Besar Program Pengajaran (GBPP) SD meliputi: atletik, senam, permainan dan pendidikan kesehatan, sedangkan pilihan yang disediakan meliputi: Renang, pencak silat, tenis meja dan sepak takraw (Depdikbud, 1993).

Kesegaran jasmani adalah suatu "kemampuan yang menitik beratkan pada fungsi-fungsi biologis yaitu kemampuan jantung, pembuluh darah, paru dan otot yang berfungsi pada efisiensi yang optimal" (Gusril, 2004:184). Adanya bidang

PJKR_

http://jurnal.unimed.ac.id/2012/index.php/jpehr/index 
studi pendidikan jasmani olahraga dan kesehatan diharapkan siswi dapat mempunyai kesegaran jasmani yang baik. Kesegaran jasmani adalah "aspek fisik dari kesegaran yang menyeluruh (total fitness) yang memberikan kepada seseorang untuk menjalankan idup yang produktif serta dapat menyesuaikan diri pada pembebaan fisik yang layak" (Arsil, 2008).

Berdasarkan kutipan yang dikemukakan, berarti kesegaran jasmani merupakan cermin dari kemampuan fungsi serta sistem-sistem dalam tubuh yang dapat mewujudkan suatu peningkatan kualitas hidup dalam setiap aktifias fisik, kesegaran jasmani merupakan kemampuan fisik yang dapat dilatih melalui program latihan kemampuan aerobik antara lain dapat diketahui melalui sistem kardiorespiratori untuk menyediakan kebutuhan oksigen sampai ke dalam mitokondria, sedangkan kemampuan anaerobik yang diukur dari kemampuan ambangan aerobik dan kekuatan kontraksi otot.

Aktifitas setiap anak berbeda dari cara mereka bermain dan kegiatan mereka sehari-hari. Di lihat pada siswi SD di desa aktifitas sehari mereka lebih banyak dan menantang, seperti pergi sekolah berjalan kaki, pulang sekolah bermain ke sawah, mandi ke sungai dan mencari kegiatan di alam. Bahkan ada yang menempuh jarak cukup jauh ke sekolah. Berbeda sekali dengan SD di kota, siswi bersekolah antar jemput transportasi, di samping itu jenis permainan yang dilakukan siswi juga berbeda, sebagian besar dari siswi SD di kota lebih banyak aktifitasnya mempelajari mata peljaran yang dipelajari (les atau bimbingan belajar). Berdasarkan uraian dan realita di atas berkemungkinan aktifitas fisik sehari-hari pada anak mempengaruhi kesegaran anak.

Mata pelajaran penjas dan kesehatan perlu dilaksanakan disetiap sekolah sesuai dengan kurikulum pendidikan untuk membina kesegaran jasmani, kesehatan dan rohani anak didik. Pembelajaran penjasorkes disekolah perlu mempertimbangkan aspek kondisi sekolah, lingkungan geografis dan status ekonomi orang tua siswa, serta asupan gizi yang dikonsumsi. Di desa ekonomi para wali murid/orang tua rata-rata menengah ke bawah, banyak orang tua yang bekerja sebagai buruh tani dan kuli bangunan. Orang tua tidak begitu mengerti dengan asupan gizi yang dibutuhkan anak, keadaan seperti ini akan berimbas pada kondisi anak serta gizi anak tidak terpenuhi Ada sekolah yang dapat menyediakan sarana dan prasarana tetapi ada juga sekolah yang tidak dapat menyediakan sarana pendukung pendidikan kesegaran jasmani dan kesehatan. Wijantosa dalam Gusril (2004-36) mengatakan bahwa sarana dan prasarana sangat besar pengaruhnya terhadap pelaksanaan program penjas. Untuk menciptakan pembelajaran penjas yang berkualitas diperlukan sarana dan prasarana yang memadai.

Berdasarkan uraian yang dikemukakan di atas dan juga terdapat perbedaan sekolah antara SDN 13 Muara Siberut dengan siswa SDN 06 Rogdog Kecamatan Siberut Selatan belum dapat dipastikan bahwa siswa SDN 13 Muara Siberut mempunyai tingkat kesegaran jasmani yang lebih baik dari pada siswa SDN 06 Rogdog Kecamatan Siberut Selatan. Untuk itu perlu dilakukan penelitian tentang perbedaan tingkat kesegaran jasmani siswa SDN 13 Muara Siberut dan siswa SDN 06 Rogdog Kecamatan Siberut Selatan.

PJKR_

http://jurnal.unimed.ac.id/2012/index.php/jpehr/index 


\section{Metode}

Penelitian ini tergolong penelitian komparasi yaitu untuk membandingkan hasil dari dua kelompok data, adapun kerangka konseptual yang dapat digambarkan sebagai berikut:

\section{Gambar 1. Kerangka Konseptual}

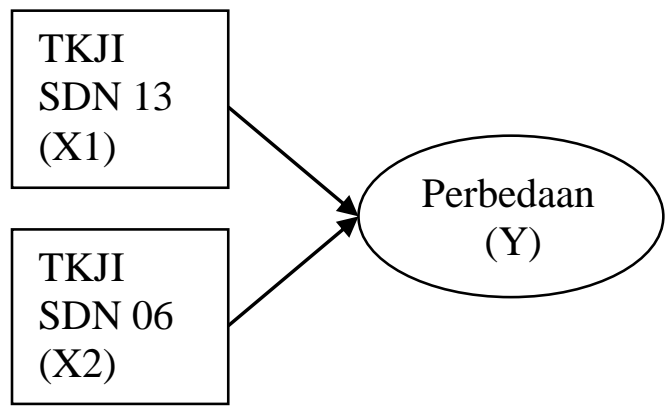

Populasi dalam penelitian ini berjumlah 59 orang siswa kelas V SDN 13 Muara Siberut dengan siswa SDN 06 Rogdog, rincianya dapat dilihat pada tabel:

Tabel 1: Jumlah Populasi

\begin{tabular}{|c|c|c|c|c|}
\hline No & Sekolah & \multicolumn{2}{|c|}{ Kelas V } & Jumlah \\
\hline & & $\mathrm{Pa}$ & $\mathrm{Pi}$ & \\
\hline 1 & SDN 13 & 17 & 22 & 39 \\
\hline 2 & SDN 06 & 19 & 25 & 44 \\
\hline & \multicolumn{3}{|c|}{ Jumlah Populasi } & 83 \\
\hline
\end{tabular}

Pengambilan sampel dalam penelitian ini menggunakan teknik Random Sampel, yang merupakan pengambilan sampel bersyarat. Alasan penulis mengambil sampel perempuan karena pada umumnya perempuan kurang suka melakukan aktifitas gerak daripada laki-laki dan perempuan tidak suka berkeringat berlebihan. Berdasarkan hal tersebut maka sampel yang didapat adalah siswi putri kelas V, SDN 13 Muara Siberut sebanyak 10 orang siswi dan SDN 06 Rogdog sebanyak 15 orang siswi, semua berjumlah 25 orang.

Pelaksanaan tes menggunakan jenis tes kesegaran jasmani Indonesia untuk anak umur 10 s/d 12 tahun, yaitu: 1) Lari cepat jarak 40 meter, 2) Angkat gantung siku tekuk, 3) Baring duduk selama 30 detik, 4) Loncat tegak, 5) Lari/jalan jarak 600 meter.

Hal yang harus diperhatikan dalam pelaksanaan tes, peserta harus dalam keadaan sehat, memakai pakaian olahraga dan melakukan pemanasan (warming-

PJKR_

http://jurnal.unimed.ac.id/2012/index.php/jpehr/index 
up) sebelum melakukan tes. Tes kesegaran jasmani merupakan satu rangkaian tes yang harus dilaksanakan dalam satu kegiatan yang tidak terputus dan jika tidak dapat melaksanakan satu butir tes atau lebih dinyatakan gagal.

\section{Pelaksanaan tes}

1) Lari 40 meter, bertujuan untuk mengukur kecepatan, alat dan fasilitas lintasan lurus, datar, dan tidak licin berjarak 40 meter dan masih mempunyai lintasan lanjutan, bendera start, peluit, stopwatch, nomor dada dan alat tulis. Bentuk pelaksanaan tes, aba-aba 'bersedia' peserta menempatkan diri start melayang di belakang garis start, aba-aba 'siap' peserta siap untuk lari, aba-aba 'ya' peserta lari secepat mungkin menuju finish.

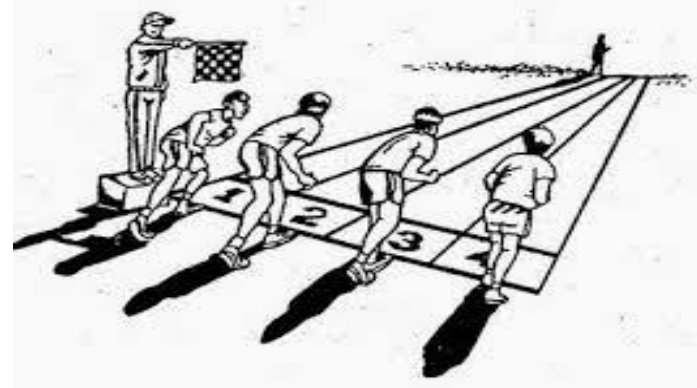

Gambar 2. Start lari 40 meter

2) Tes gantung siku tekuk, bertujuan mengukur kekuatan dan ketahanan otot lengan dan otot bahu, alat dan fasilitas palang tunggal yang dapat dinaikan dan diturunkan, stopwatch, alat tulis, nomor dada dan serbuk kapur. Bentuk pelaksanaan, palang tunggal dipasang dengan ketinggian sedikit diatas kepala peserta, peserta berdiri di bawah palang tunggal, kedua tangan berpegangan pada palang tunggal selebar bahu, pegangan telapak tangan mengahadap kearah letak kepala, peserta melompat keatas sampai sikap bergantung siku teguk, dagu berada diatas palang tunggal, dipertahankan selama detik.

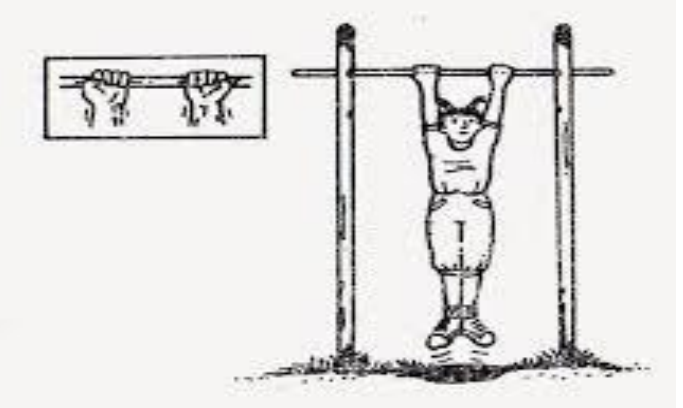

Gambar 3. Sikap permulaan gantung siku tekuk

3) Tes baring duduk 30 detik, bertujuan untuk mengukur kekuatan dan ketahanan otot perut. Bentuk pelaksanaan berbaring terlentang, kedua lutut ditekuk 90 derajat, kedua tangan dibelakang kepala, petugas memegang 
pergelangan kaki peserta. Aba-aba 'ya' peserta bergerak mengambil sikap duduk sampai kedua siku menyentuh kedua paha, kemudian kembali ke sikap semula, gerakan dilakukan berulang-ulang dengan cepat tanpa istirahat selama 30 detik, hasil dihitung jumlah gerakan baring duduk sempurna selama 30 detik.

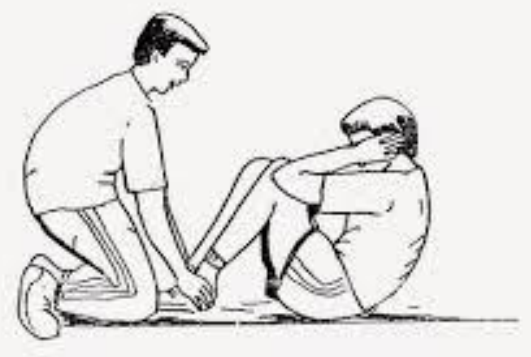

Gambar 4. Sikap duduk dengan kedua siku menyentuh paha

4) Tes loncat tegak, bertujuan mengukur tenaga eksplosif, alat dan fasilitas papan berskala sentimeter, warna gelap, ukuran 30x150 cm dipasang pada dinding/tiang, jarak antara lantai dengan angka nol pada skala, yaitu $100 \mathrm{~cm}$. Bentuk pelaksaan, olesi ujung jari dengan serbuk kapur, peserta berdiri tegak dekat dinding, kaki rapat, papan skala berada di samping kiri/kanan, tangan yang dekat dinding diangkat lurus ke atas telapak tangan ditempelkan pada papan berskala, sehingga meninggalkan bekas raihan jarinya. Selanjutnya, peserta mengambil awalan sikap menekukan lutut dan kedua lengan diayun kebelakang, kemudian peserta loncat setinggi mungkin sambil menepuk papan dengan tangan yang terdekat sehingga menimbulkan bekas. Hasil yang dicatat yaitu selisish raihan loncatan dikurangi raihan gerak.
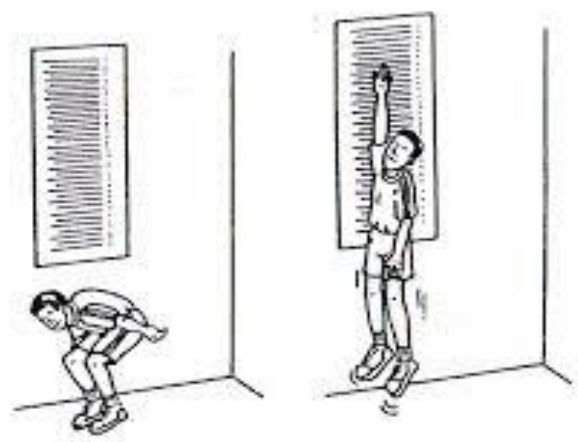

Gambar 5. Sikap awalan loncat tegak dan menloncat setinggi mungkin

5) Tes lari 600 meter, bertujuan mengukur daya tahan jantung, peredaran darah dan pernafasan. Alat dan fasilitas lintasan lari berjarak 600 meter, stopwatch, bendera start, peluit, tiang pancang, formulir tes. Petugas tes terdiri dari: juru keberangkatan, pengukur waktu, pencatat hasil. Pelaksanaan tes, peserta berdiri di belakang garis start, aba-aba 'SIAP' peserta mengambil sikap start berdiri siap untuk berlari, aba-aba 'YA' 
peserta berlari menuju garis finish menempuh jarak 600 meter. Hasil pengambilan waktu dilakukan dari saat bendera diangkat sampai pelari melintasi garis finish, hasil dicatat dalam satuan menit dan detik.

Menentukan tingkat kesegaran jasmani, ikuti langkah-langkah berikut: 1 . Jumlahkan nilai kelima tes $(1 \mathrm{~s} / \mathrm{d} 5)$ 2. Cocokan hasil penjumlahan nilai dengan Norma Tes Kesegaran Jasmani Indonesia.

Tabel 3. TKJI anak usia 10-12tahun Putri

\begin{tabular}{|c|c|c|c|c|c|}
\hline \multirow[t]{2}{*}{ Nilai } & \multirow{2}{*}{$\begin{array}{c}\text { Lari } 40 \\
\text { meter }\end{array}$} & $\begin{array}{c}\text { Gantung } \\
\text { siku } \\
\text { tekuk } \\
\end{array}$ & $\begin{array}{l}\text { Baring } \\
\text { duduk }\end{array}$ & \multirow{2}{*}{$\begin{array}{c}\text { Loncat } \\
\text { tegak }(\mathrm{cm})\end{array}$} & \multirow{2}{*}{$\begin{array}{c}\text { Lari } 600 \\
\text { meter }\end{array}$} \\
\hline & & (detik) & $\begin{array}{l}\text { (30 } \\
\text { detik) }\end{array}$ & & \\
\hline 5 & Sd-6.3” & $\begin{array}{l}40 " \mathrm{ke} \\
\text { atas }\end{array}$ & $\begin{array}{l}20 \mathrm{ke} \\
\text { atas }\end{array}$ & 42 ke atas & Sd-2’32 \\
\hline 4 & $6.8 "-7.5 "$ & $20 "-39 "$ & 14-19 & $34-41$ & 2'33"'-2'54" \\
\hline 3 & $7.6 "-8.3 "$ & 8"'-19" & $7-13$ & $28-33$ & 2'55"-3'28' \\
\hline 2 & 8.4"-9.6" & 2"-7" & $2-6$ & $21-27$ & 3'29"-4'22" \\
\hline 1 & 9.7'”-dst & 0"-1" & $0-1$ & $20-d s t$ & 4'23"-dst \\
\hline
\end{tabular}


Tabel 4. Norma TKJI

\begin{tabular}{|c|c|c|}
\hline No & Jumlah nilai & Klasifikasi \\
\hline 1 & $22-25$ & Baik Sekali (BS) \\
\hline 2 & $18-21$ & Baik (B) \\
\hline 3 & $14-17$ & Sedang (S) \\
\hline 4 & $10-13$ & Kurang (K) \\
\hline 5 & $5-9$ & Kurang Sekali (KS) \\
\hline
\end{tabular}

\section{Pembahasan}

Data kesegaran jasmani siswi SD Negeri 13 Muara Siberut Siberut Selatan, diperoleh dari skor yang dicapai melalui rangkaian tes dalam tes kesegaran jasmani. Sampel sebanyak 10 orang siswi, skor tertinggi 15 dan skor terendah 8, rentangan 7, rata-rata 13.10, simpangan baku 2.02, modus 14 .

\section{Tabel 5. Distribusi TKJI siswi SD Negeri 13 Muara Siberut Siberut Selatan}

\begin{tabular}{|l|l|l|l|c|}
\hline No & $\begin{array}{c}\text { Kelas } \\
\text { Interval }\end{array}$ & $\begin{array}{c}\text { Frekuensi } \\
\text { Absolut }\end{array}$ & $\begin{array}{c}\text { Frekuensi } \\
\text { Relatif } \\
(\%)\end{array}$ & Kategori \\
\hline 1 & $22-25$ & 0 & 0 & Baik Sekali \\
\hline 2 & $18-21$ & 0 & 0 & Baik \\
\hline 3 & $14-17$ & 7 & 70 & Sedang \\
\hline 4 & $10-13$ & 2 & 20 & Kurang \\
\hline 5 & $5-9$ & 1 & 10 & Kurang Sekali \\
\hline \multicolumn{2}{|l}{ Jumlah } & 10 & 100 & \\
\hline
\end{tabular}

Data kesegaran jasmani siswi SD Negeri 06 rogdog, diperoleh dari skor yang dicapai melalui rangkaian tes dalam tes kesegaran jasmani. Sampel sebanyak 15 orang siswi, skor tertinggi 13 dan skor terendah 8 , rentangan 5 , ratarata 11.13, simpangan baku 1.46, modus 12 . 
Tabel 6. Distribusi TKJI siswi SD Negeri 06 Rogdog

\begin{tabular}{|c|c|c|c|c|}
\hline No & $\begin{array}{c}\text { Kelas } \\
\text { Interval }\end{array}$ & $\begin{array}{c}\text { Frekuensi } \\
\text { Absolut }\end{array}$ & $\begin{array}{c}\text { Frekuen } \\
\text { si Relatif } \\
(\boldsymbol{\%})\end{array}$ & Kategori \\
\hline 1 & $22-25$ & 0 & 0 & $\begin{array}{c}\text { Baik } \\
\text { Sekali }\end{array}$ \\
\hline 2 & $18-21$ & 0 & 0 & Baik \\
\hline 3 & $14-17$ & 0 & 0 & Sedang \\
\hline 4 & $10-13$ & 13 & 86.7 & Kurang \\
\hline 5 & $5-9$ & 2 & 13.3 & $\begin{array}{c}\text { Kurang } \\
\text { Sekali }\end{array}$ \\
\hline \multicolumn{2}{|c|}{ Jumlah } & $\mathbf{1 5}$ & $\mathbf{1 0 0}$ & \\
\hline
\end{tabular}

Berdasarkan hasil perhitungatn uji homogenitas ditemukan bahwa harga $F_{\text {hitung }}$ yang diperoleh lebih kecil dari harga $F_{\text {tabel }}$ dengan derajat kebebasan (n1-1) (n2-2) dan taraf signifikasi 0,05. Dengan demikian dapat disimpulkan bahwa semua kelompok data pada penelitian ini diambil dari populasi yang berdistribusi normal sehingga dapat digunakan pengujian hipotesis penelitian. Pengujian Hipotesis penelitian ini dilakukan dengan teknik uji-t.

Berdasarkan hasil uji hipotesis d hasil thitung $(2,66)$ yangdilihat dari taraf signifikasi 0,05 dan $\mathrm{dk}(\mathrm{n} 1-1)$ dan $(\mathrm{n} 2-2)$, maka diperoleh $\mathrm{t}_{\text {tabel }}(\mathrm{n} 1=2,26)$ dan $(\mathrm{n} 2=2,14)$, selanjutnya dapat dila kukan perhitungan $\mathrm{t}_{\mathrm{alpha}}=1,88$

Dengan demikian dapat disimpulkan bahwa terdapat perbedaan antara hasil tes kesegaran jasmani siswi SDN 13 Muara Siberut dengan tingkat kesegaran jasmani siswi SDN 06 Rogdog Kecamatan Siberut Selatan.

\section{Simpulan}

Berdasarkan hasil analisis data tentang perbedaan tingkat kesegaran jasmani siswi SDN 13 Muara Siberut dengan SDN 06 Rogdog Kecamatan Siberut Selatan, dapat ditarik kesimpulan bahwa: terdapat perbedaan tingkat kesegaran jasmani siswi SDN 13 Muara Siberut tergolong ke dalam kategori sedang, sedangkan siswi SDN 06 Rogdog Kecamatan Siberut Selatan tergolong ke dalam kategori kesegaran jasmani kurang

\section{Rujukan}

Arikunto, Suharsimi. 2002. Prosedur Penelitian. Jakarta: Rineka Cipta Arsil, 2004. Pembinaan Kondisi Fisik. Padang: FIK UNP , 2004. Pembinaan Kondisi Fisik. Padang: FIK UNP 2010. Evaluasi Penjas dan Olahraga. Padang: Wineka Media

Depdikbud, 1993. Garis-Garis Besar Program Pengajaran. Jakarta: Direktorat Jenderal Pendidikan 2004. Hasil Seminar Kesegaran Jasmani.. Jakarta: Depdikbud 
Gusril, 2004. Perkembangan Motorik Pada Masa Anak-anak. Jakarta: Dirjen Olahraga Depdiknas , 2008. Model Pengembangan Motorik Pada Siswa Sekolah Dasar. Jakarta: Dirjen Olahraga Depdiknas

Ridwan, 2004. Statistika Untuk Lembaga dan Instansi Pemerintahan/Swasta. Bandung: Alfabeta

Rusli, Lutan, 2002. Azas-azas Pendidikan Jasmani. Jakarta: Dirjen Olahraga Suharno, 1986. Ilmu Pelatihan Olahraga. Yogyakarta: Yayasan STO

Undang-undang No.23 tahun 2003. Tentang Fungsi dan Tujuan Sistem Pendidikan Nasional. Jakarta: BP Cipta Jaya 